The level of lead in the water of the rural population was in some instances of the same range as the urban group with leadlined tanks. The cause of the presence of symptoms in the rural subjects and the absence of symptoms in the urban subjects requires consideration. The investigation of the rural subjects was prompted initially by their presentation with symptoms, while the urban study was entirely epidemiological. The durations of exposure in the five patients of the rural group who had symptoms ranged from 15 to 50 years, higher with one exception than in the urban group with lead tanks. This may be another factor to explain the difference in the incidence of symptoms.

Our acknowledgements are due to Sir Hector MacLennan for permission to report on Family 2 and to Dr. K. J. MacDonald, of Bonar Bridge, for his help in obtaining samples from Families 1 and 4. This study was supported by a grant from the Advisory Committee on Medical Research of the Secretary of State for Scotland.

\section{References}

Bacon, A. P. C., Froome, K., Gent, A. E., Cooke, T. K., and Sowerby, P. (1967). Lancet, 1, 265.

Bauer, W., and Krane, S. M. (1964). Diseases of Metabolism, 5th edn., p. 833. Philadelphia, Saunders.

Beattie, A. D., Moore, M. R., Devenay, J., Miller, A. R., and Goldberg, A. (1972). British Medical fournal, 2, 491.

Crawford, M. D., and Morris, J. N. (1967). Lancet, 2, 1087.

Crawford, M. D., and Morris, J. N. (1967). Lancet, 2, 1087.

Gibson, Sheila, Lam, C. N., McCrae, W. M., and Goldberg, A. (1967). Archives of Diseases in Childhood, 42, 226.

Gibson, Sheila, Mackenzie, J. C., and Goldberg, A. (1968). British fournal of Industrial Medicine, 25, 40 .

Lane, R. E. et al. (1968). British Medical fournal, 4, 501.

Major, R. H. (1965). Classic Descriptions of Disease, 3rd edn., revised, p. 311 Illinois, Thomas.

Mauzerall, D., and Granick, S. (1956). Fournal of Biological Chemistry, 219, 435.

Moncrieff, A. A. et al. (1964). Archives of Diseases in Childhood, 39, 1.

Rimington, C. (1961). Association of Clinical Pathologists, Broadsheet No. 36.

Waldron, H. A. (1966). British fournal of Industrial Medicine, 23, 83

Wilson, A. T. (1966). Scottish Medical fournal, 11, 73.

World Health Organization (1971). International Standards for Drinking Water. W. H. O., Geneva.

\title{
Environmental Lead Pollution in an Urban Soft-water Area
}

\author{
A. D. BEATTIE, M. R. MOORE, W. T. DEVENAY, A. R. MILLER, A. GOLDBERG
}

British Medical fournal, 1972, 2, 491-493

\section{Summary}

An investigation has been reported on the clinical and metabolic effects of lead acquired by soft domestic water from lead plumbing systems in 23 Glasgow households. The lead content of water from cold taps was up to 18 times the upper acceptable limit and was proportional to the amount of lead in the plumbing system. The blood lead of 71 inhabitants of these houses showed a significant positive correlation with water lead content. Deltaaminolaevulic acid dehydrase activity, an extremely sensitive indicator of lead exposure, showed a significant negative correlation with water-lead content. Atmospheric lead was within acceptable limits in all but one house and no significant correlation could be found with biochemical measurements. A small number of clinical abnormalities were found but could not be directly attributed to lead toxicity. The results of the study underline the possible danger to health of lead plumbing systems in soft-water regions.

\section{Introduction}

A number of cases of lead poisoning from ingestion of domestic water have been described in recent years (Bacon et al., 1967; Beattie et al., 1972). In these cases lead was acquired by soft moorland water from lead tanks and lead pipes. There is evidence that soft water has a greater avidity for lead than hard M.R.C. Group in Iron and Porphyrin Metabolism, Stobhill Hospital,
Glasgow N.1

A. D. BEATTIE, M.B., CH.B., Honorary Registrar A. GOLDBERG, M.D., F.R.C.P., F.R.S.ED., Regius Professor of Materia

M. R. MOORE, B.SC., PH.D., Research Biochemist

Lower Clyde Water Board

W. T. DEVENAY, B.Sc., Deputy Water Engineer

Health Department, Corporation of Glasgow

A. R. MILLER, M.D., D.P.H., Medical Officer of Health (retired June 1971) water, which may form a shield of calcium salts over the lead surface of the pipes (Crawford and Morris, 1967). While the clinical effect of lead in severe cases can be shown little is known about the subclinical consequences of drinking lead-contaminated water over a long period of time. The present study of the clinical and metabolic effects of lead ingested in drinking water was made in Glasgow, which is one of the largest soft-water areas of the United Kingdom.

\section{Materials and Methods}

The subjects studied were 71 volunteers from 23 families in whom the householder was an employee of either the Lower Clyde Water Board or the Health and Welfare Department of the Corporation of Glasgow. There was, in fact, a total of 73 members of these families but one was a 6-month old baby and another an adult female who was unwilling to take part in the study. Employees whose occupation involved contact with lead were excluded. A sample of tap-water taken first thing in the morning without previous running of the tap was obtained in lead-free plastic containers from each household. Water lead was measured in this sample by the dithizone method (Gonzales et al., 1954). A sample of water was also obtained from the reservoir serving the area of the study.

A questionnaire was completed for each household asking the type of house, its age, and the duration of occupation by the family. An accurate assessment of the plumbing system was made with respect to the presence or absence of a tank for storage of cold water, the type of tank, and the absolute length of each type of pipe carrying the cold water from the mains supply to the kitchen tap. The questionnaire also asked about symptoms and signs which are known to occur in lead poisoning. The items are shown in the Fig. An effort was made to establish which member of the household was first to drink tap-water each morning.

Samples of blood and urine were obtained from each subject. Blood lead was measured by the dithizone method. Deltaaminolaevulic acid dehydrase (ALA dehydrase) was measured in erythrocytes by the method of Moore et al. (1971). Serum urea and uric acid were measured by standard techniques. A blood 


\section{LEAD POISONING SURVEY}

Name

Age Occupation

General Practitioner -

$$
\begin{aligned}
& \text { A. Tiredness YES Dyspnoea YES Paraesthesia YES } \\
& \text { B. Vomiting YES Abd.poin YES Diarrhoea YES } \\
& \text { Constipation YES }
\end{aligned}
$$

C. Headaches NOS B.P. $=\mathrm{mmHg}_{\mathrm{g}}$

D. Weokness of limbs YES NO Tremor

E. Joint pain NOS Joint stiffness YES

F. Intelligence:

School performance:

G. Alcohol

Questionnaire completed by all households in the survey to assess symptoms and signs known to occur in lead poisoning.

film was examined and the haemoglobin measured. Urinary delta-aminolaevulic acid (ALA) and coproporphyrin were measured by the methods of Mauzerall and Granick (1956) and Rimington (1961) respectively. Urinary protein was detected by use of the Albustix test.

Atmospheric lead was measured in each house over a 24-hour period by means of a medium volume sampler at $10 \mathrm{l} . / \mathrm{min}$, the sample being collected on microsorband filters. Total lead content was estimated with a Perkin-Elmer 290 atomic absorption spectrophotometer.

\section{Results}

The habitations occupied by the 23 families consisted of 12 semi-detached or terraced houses, nine flats, and two detached houses. The ages of these houses ranged from 5 to 60 years, mean 26.3 years. Each family had occupied their house for a minimum of five years, the average occupation being 13 years. For the purposes of the study the houses were allocated to one of three groups. In group 1 (six houses) the cold water was stored in a lead-lined tank and distributed to the taps through lead piping. In group 2 (six houses) there were no lead tanks but the cold water passed through at least 60 feet $(18 \mathrm{~m})$ of lead pipes before reaching the kitchen tap. It was almost impossible to find a lead-free plumbing system and so group 3 ( 11 houses) was formed by houses with less than 60 feet of lead piping between the mains and the kitchen cold tap. Twenty-two subjects lived in group 1 houses, 24 in group 2 houses, and 25 in group 3 houses.

The lead content of the water from each house is shown in Table I together with the age of the house, the duration of occupation by the family, and the length of lead piping. The average water lead content of the 23 houses was $358 \mu \mathrm{g} / \mathrm{l}$. In groups 1, 2, and 3 the average water leads were $934 \mu \mathrm{g}, 239 \mu \mathrm{g}$, and $108 \mu \mathrm{g} / \mathrm{l}$. respectively. There were significant differences in water lead between group 1 and group $2(P<0.01)$ and between group 2 and group $3(P<0.02)$. With the exclusion of group 1 , in which there were lead-lined tanks, there was a significant positive correlation between the length of lead piping and the water lead $(r=0.754, P<0.05)$. The average age of houses in groups 1 and 2 (36 years) was significantly higher than that of group 3 houses $(15.4$ years $)(P<0.001)$. The positive correlation referred to between the length of lead piping and the water lead content pertains for houses of less than 20 years just as much as for older houses.

The lead content of the water sample obtained from the main reservoir serving the area was $17 \cdot 9 \mu \mathrm{g} / \mathrm{l}$.

The lead content of the atmosphere within the houses ranged from nil to $11.1 \mu \mathrm{g} / \mathrm{m}^{3}$, with a mean of $1.46 \mu \mathrm{g} / \mathrm{m}^{3}$. No significant correlation could be found between atmospheric lead and any of the clinical or biochemical measurements.

Six subjects complained of abdominal pain. All were within groups 1 and 2 but in each case the blood lead was within normal limits. Dyspnoea and joint pains were common complaints but no relation to biochemical abnormalities or to a raised water lead could be deduced. Six had a diastolic blood pressure of $95 \mathrm{~mm} \mathrm{Hg}$ or more, and this group had a higher mean blood lead of $33.4 \mu \mathrm{g} / 100 \mathrm{~g}$ than the normotensive members of the study (mean blood lead $22.7 \mu \mathrm{g} / 100 \mathrm{~g}$ ); however, no statistical significance can be attached to the small numbers involved.

The principal biochemical findings in the subjects studied are shown in Table II. When taking an upper limit of blood

\begin{tabular}{|c|c|c|c|c|c|c|c|c|c|c|c|c|c|c|c|c|c|}
\hline \multicolumn{6}{|c|}{$\begin{array}{c}\text { Group 1 } \\
\text { Lead-lined Tank }\end{array}$} & \multicolumn{6}{|c|}{$\begin{array}{c}\text { Group } 2 \\
\text { Lead Piping }>60 \mathrm{ft}(18 \mathrm{~m})\end{array}$} & \multicolumn{6}{|c|}{$\begin{array}{c}\text { Group } 3 \\
\text { Lead Piping }<60 \mathrm{ft}(18 \mathrm{~m})\end{array}$} \\
\hline \multirow{2}{*}{$\begin{array}{l}\text { House } \\
\text { No. }\end{array}$} & \multirow{2}{*}{$\begin{array}{c}\text { Age } \\
\text { (Years) }\end{array}$} & \multirow{2}{*}{$\begin{array}{c}\text { Occupa- } \\
\text { tion } \\
\text { (Years) }\end{array}$} & \multicolumn{2}{|c|}{ Lead Pipe } & \multirow{2}{*}{$\begin{array}{l}\text { Water } \\
\text { Lead } \\
(\mu \mathrm{g} / \mathrm{l} .)\end{array}$} & \multirow{2}{*}{$\begin{array}{l}\text { House } \\
\text { No. }\end{array}$} & \multirow{2}{*}{$\begin{array}{c}\text { Age } \\
\text { (Years) }\end{array}$} & \multirow{2}{*}{$\begin{array}{c}\text { Occupa- } \\
\text { tion } \\
\text { (Years) }\end{array}$} & \multicolumn{2}{|c|}{ Lead Pipe } & \multirow{2}{*}{$\begin{array}{c}\text { Water } \\
\text { Lead } \\
(\mu \mathrm{g} / 1 .)\end{array}$} & \multirow{2}{*}{$\begin{array}{l}\text { House } \\
\text { No. }\end{array}$} & \multirow{2}{*}{$\begin{array}{c}\text { Age } \\
\text { (Years) }\end{array}$} & \multirow{2}{*}{$\begin{array}{c}\text { Occupa- } \\
\text { tion } \\
\text { (Years) }\end{array}$} & \multicolumn{2}{|c|}{ Lead Pipe } & \multirow{2}{*}{$\begin{array}{l}\text { Water } \\
\text { Lead } \\
(\mu \mathrm{g} / \mathrm{l} .)\end{array}$} \\
\hline & & & $\mathrm{ft}$ & $\mathbf{m}$ & & & & & $\mathrm{ft}$ & $m$ & & & & & $\mathrm{ft}$ & $\mathbf{m}$ & \\
\hline 1 & 45 & 6 & 99 & $30 \cdot 0$ & 1,005 & 7 & 16 & 7 & 150 & $45 \cdot 5$ & 450 & 13 & 20 & 20 & 54 & 16.5 & 161 \\
\hline 2 & 35 & 7 & 143 & 34.5 & 1,850 & 8 & 45 & 14 & 100 & 30.5 & 245 & $\begin{array}{l}14 \\
15\end{array}$ & $\begin{array}{l}14 \\
11\end{array}$ & 11 & 36 & $\begin{array}{l}10.0 \\
11.0\end{array}$ & $\begin{array}{l}58 \\
78\end{array}$ \\
\hline 3 & 37 & 37 & 104 & 31.5 & 700 & 9 & 25 & 20 & 62 & $19 \cdot 0$ & 250 & $\begin{array}{l}16 \\
17\end{array}$ & $\begin{array}{r}10 \\
5\end{array}$ & $\begin{array}{l}8 \\
5\end{array}$ & $\begin{array}{r}9 \\
\mathrm{Nil}\end{array}$ & $\begin{array}{l}2 \cdot 7 \\
\text { Nil }\end{array}$ & $\begin{array}{l}28 \\
35\end{array}$ \\
\hline 4 & 35 & 7 & 82 & $25 \cdot 0$ & 760 & 10 & 30 & 15 & 132 & $40 \cdot 0$ & 215 & $\begin{array}{l}18 \\
19\end{array}$ & $\begin{array}{l}16 \\
20\end{array}$ & $\begin{array}{l}16 \\
15\end{array}$ & $\begin{array}{l}31 \\
24\end{array}$ & $\begin{array}{l}9.5 \\
7.0\end{array}$ & $\begin{array}{l}65 \\
72\end{array}$ \\
\hline 5 & 45 & 16 & 144 & $44 \cdot 0$ & 1,000 & 11 & 20 & 10 & 89 & $27 \cdot 0$ & 105 & $\begin{array}{l}20 \\
21\end{array}$ & $\begin{array}{l}30 \\
16\end{array}$ & $\begin{array}{r}15 \\
6\end{array}$ & $\begin{array}{l}49 \\
24\end{array}$ & $\begin{array}{r}15 \cdot 0 \\
7.0\end{array}$ & $\begin{array}{r}252 \\
13\end{array}$ \\
\hline 6 & 37 & 10 & 131 & $40 \cdot 0$ & 310 & 12 & 60 & 24 & 76 & 23.0 & 167 & $\begin{array}{l}22 \\
23\end{array}$ & $\begin{array}{l}11 \\
16\end{array}$ & $\begin{array}{r}11 \\
8\end{array}$ & $\begin{array}{r}4 \\
59\end{array}$ & $\begin{array}{r}1.2 \\
18.0\end{array}$ & $\begin{array}{l}180 \\
245\end{array}$ \\
\hline
\end{tabular}
lead of $40 \mu \mathrm{g} / 100 \mathrm{ml}$ four subjects had raised values. Three of these were in group 1 and one was in group 2. The two highest

\begin{tabular}{|c|c|c|c|c|c|c|}
\hline & & & & Group 1 & Group 2 & Group 3 \\
\hline $\begin{array}{l}\text { Blood lead }(\mu \mathrm{g} / 100 \mathrm{~g}) \\
\text { Erythrocyte ALA dehydrase (nmol } \\
\text { Urinary ALA (mg/100 ml). } \\
\text { Urinary coproporphyrin }(\mu \mathrm{g} / \mathrm{l} .) \\
\text { Serum urea (mg } / 100 \mathrm{ml}) \\
\text { Serum uric acid }(\mathrm{mg} / 100 \mathrm{ml}) \\
\text { Haemoglobin }(\mathrm{g} / 100 \mathrm{ml}) \quad \ldots\end{array}$ & $\begin{array}{ll}\because & \ddot{P} . G . B . / 10^{10} \\
\because & \cdots \\
\because & \cdots \\
\because & \cdots \\
\cdots & \cdots\end{array}$ & $\begin{array}{lc}\text { R.B.C./hr) } \\
\because \cdots \\
\because & \cdots \\
\because & \cdots \\
\cdots & \cdots\end{array}$ & $\begin{array}{l}\cdots \\
\cdots \\
\cdots \\
\cdots \\
\cdots\end{array}$ & $\begin{array}{l}28 \cdot 4 \pm 13 \cdot 0 \\
379 \pm 211 \\
0 \cdot 48 \pm 0 \cdot 17 \\
78 \cdot 3 \pm 48 \cdot 9 \\
28 \cdot 3 \pm 6 \cdot 6 \\
4.5 \pm 0.9 \\
14 \cdot 1 \pm 1 \cdot 9\end{array}$ & $\begin{array}{l}24.4 \pm 6.5 \\
504 \pm 116 \\
0.47 \pm 0.22 \\
86.5 \pm 41.4 \\
32.6 \pm 9.5 \\
4.4 \pm 1.0 \\
14.5 \pm 1.7\end{array}$ & $\begin{array}{l}18 \cdot 7 \pm 7 \cdot 3 \\
528 \pm 152 \\
0 \cdot 28 \pm 0 \cdot 15 \\
51 \cdot 7 \pm 32 \cdot 5 \\
29 \cdot 6 \pm 5 \cdot 1 \\
5.0 \pm \pm 1.0 \\
14.9 \pm 1.5\end{array}$ \\
\hline
\end{tabular}

TABLE I-Age, Duration of Occupation, Extent of Lead Plumbing, and Water Lead in the 23 Houses

TABLE II-Blood and Urinary Findings in 71 Subjects in the Three Groups. Mean \pm Standard Deviation are given in Each Case. 
levels were in two men living in the house (No. 2) with the highest water lead level. There was a highly significant correlation between blood leads and water leads $(r=0.599, P<0.001)$. The difference in blood lead between group 1 and group 2 was not significant but between group 2 and group 3 it was significant $(P<0.02)$. Between group 1 and group 3 the significance was greater $(P<0.001)$. There were no significant differences in blood lead levels between men and women nor between adults and children, although four children were found to be in the upper normal range-that is, between $30 \mu \mathrm{g}$ and $40 \mu \mathrm{g} / 100 \mathrm{~g}$. The subjects who drank the first water run from the tap each morning did not have higher blood leads than the rest of the group.

There was a significant negative correlation between blood ALA dehydrase activity and water lead in the series as a whole $(r=-0.535, P<0.001)$. Twenty-three subjects in all fell below the lower limit of $415 \mathrm{nmol}$ P.B.G. $/ 10^{10}$ R.B.C./hr. Fourteen of these were in group 1, three in group 2, and six in group 3. There were significant differences between group 1 and group 2 $(P<0.05)$ and between group 1 and group $3(P<0.01)$. Blood lead varied inversely with ALA dehydrase $(r=-0.451$, $P<0.001$ ).

Nine subjects in groups 1 and 2 had urinary ALA levels exceeding the upper limit of normal of $0.6 \mathrm{mg} / 100 \mathrm{ml}$. There were significant differences in urinary ALA excretion between group 1 and group $3(P<0.01)$ and between group 2 and group $3(P<0.01)$ but not between group 1 and group 2 .

In every case the urinary coproporphyrin was within the normal range $(0-150 \mu \mathrm{g} / \mathrm{l}$.) and the levels of coproporphyrin excretion did not differ significantly between groups.

Haemoglobin, serum urea, and serum uric acid levels did not differ significantly between groups and were not correlated with water lead or atmospheric lead.

\section{Discussion}

It has been known since the days of Ancient Rome that a health hazard may result from the passage of drinking water through lead pipes (Major, 1965). Few examples of clinical disease arising from this cause have been described through the years. Bacon et al. (1967) reported three severe cases of lead poisoning from domestic water in a rural district of Yorkshire. Beattie et al. (1972) reported on 14 members of four families in the Scottish Highlands who had clinical or biochemical effects of lead exposure, including five with frank lead poisoning resulting from contaminated domestic water.

The World Health Organization (1971) suggested that the upper acceptable lead content of drinking water is $100 \mu \mathrm{g} / \mathrm{l}$. It is important to stress that in the present study the water supplied by the local authority was well within this limit and that lead contamination must have occurred within the houses from the lead tanks and pipes which carried the cold water.

Of the 23 houses only seven had water lead concentrations of less than $100 \mu \mathrm{g} / \mathrm{l}$., and all these were in the group with less than $60 \mathrm{feet}(18 \mathrm{~m})$ of lead piping. It is clear that the lead content of the cold water supplies was related to the amount of lead in the plumbing system. Older houses have more lead piping than newer houses and many of the older houses have lead tanks. It is therefore not surprising that the very high levels of water lead were found in houses built before the second world war. These houses were of good quality and might reasonably be expected to stand for many years, which suggests that the problem in this group is likely to persist for at least several decades unless the plumbing is changed.

The close relation between domestic water lead and both blood lead and ALA dehydrase in the occupants of the houses suggests that lead contamination of drinking water is likely to be an important environmental source of lead. Much attention has been directed to atmospheric lead pollution as a hazard to community health and there is evidence that certain occupational groups, such as motor-car mechanics, may have a higher blood lead level than unexposed groups. The acceptable level of atmospheric lead in domestic premises was stated by the American Industrial Hygiene Association (1969) to be not more than $10 \mu \mathrm{g} / \mathrm{m}^{3}$. This limit was slightly exceeded in one of the houses tested but the mean value of $1.46 \mu \mathrm{g} / \mathrm{m}^{3}$ was well within the limit. There was no evidence that blood lead or ALA dehydrase levels were related to atmospheric lead.

Although none of the subjects had any clamant symptoms of ill health it is of interest that the mean blood lead in six who had diastolic blood pressure in excess of $95 \mathrm{~mm} \mathrm{Hg}$ was $33.4 \mu \mathrm{g} /$ $100 \mathrm{~g}$, compared with $22.7 \mu \mathrm{g} / 100 \mathrm{~g}$ in the remaining normotensive group. These differences did not reach statistical significance and thus further work is required to elucidate the relevance of this finding.

A blood lead level of $40 \mu \mathrm{g} / 100 \mathrm{~g}$ is usually regarded as the upper limit of normal (Lane et al., 1968). By this standard four of the 71 subjects can be said to have had subclinical lead exposure. Recent work by Millar et al. (1970) showed that in children the depression of ALA dehydrase activity levels occurs at the lower level of $25-30 \mu \mathrm{g} / 100 \mathrm{~g}$. When lead was fed to lactating rats there was a commensurate reduction in both blood and brain ALA dehydrase activity in the suckling rat, and this, by inference, suggested that modest rises in blood lead might possibly be associated with biochemical abnormalities in the developing brain of the human infant. Moncrieff et al. (1964) postulated a causative role for lead in some cases of mental deficiency in children. It may therefore be of relevance that four of the 21 children (under 15 years) in the group had blood lead levels of greater than $30 \mu \mathrm{g} / 100 \mathrm{~g}$ and that in the three of these in which blood ALA dehydrase activity was measured it was reduced below the lower limit of $415 \mathrm{nmol}$ P.B.G. $/ 10^{10}$ R.B.C. $/ \mathrm{hr}$.

The implications of the study are not certain at this stage. There is no doubt that biochemical changes may result from drinking lead-contaminated water. The replacement of lead pipes would be an expensive but effective remedy. Further work on the plumbosolvency of water might be of value in predicting the effect of changing the $\mathrm{pH}$ or hardness as an alternative method of reducing the lead content.

Our acknowledgements are due to Dr. M. K. B. Molyneux and Dr. D. M. W. Hutcheson, of the Scottish Occupational Health Laboratory Service Limited, who carried out the atmospheric lead estimations, and to Mr. G. G. Thompson and Miss S. Smith for technical help.

This work was supported by a grant from the Advisory Committee on Medical Research and the Secretary of State for Scotland.

\section{References}

American Industrial Hygiene Association fournal, 1969, 30, 95.

Bacon, A. P. C., Froome, K., Gent, A. E., Cooke, T. K., and Sowerby, P. (1967). Lancet, 1, 265.

Beattie, A. D., Dagg, J. H., Goldberg, A., Wang, I., and Ronald, J. (1972). British Medical fournal, 2, 488.

Crawford, M. D., and Morris, J. N. (1967). Lancet, 2, 1087.

Crawford, M. D., and Morris, J. N. (1967). Lancet, 2, 1087. Pathology and Toxicology. New York, Appelton.

Lane, R. E., et al. (1968). British Medical fournal, 4, 501.

Major, R. H. (1965). Classic Descriptions of Disease, 3rd ed., revised, p. 311. Illinois, Thomas.

Mauzerall, D., and Granick, S. (1956). Fournal of Biological Chemistry,

Millar, J. A., Battistini, V., Cumming, R. L. C., Carswell, F., and Goldberg, A. (1970). Lancet, 2, 695.

Moncrieff, A. A., et al. (1964). Archives of Diseases in Childhood, 39, 1.

Moore, M. R., Beattie, A. D., Thompson, G. G., and Goldberg, A. (1971). Clinical Science, 40, 80.

Rimington, C. (1961). Association of Clinical Pathologists, Broadsheet No. 36 .

World Health Organization (1971). International Standards for Drinking Water. W.H.O., Geneva. 